\title{
Lending agencies plan action
}

\section{Washington}

THE major international development assistance agencies have for the first time reached a consensus on how to tackle the problem of deforestation. Not only that, but an impressive collection of environmental lobbying groups support the plan, among them some of the severest critics of the agencies' lending programmes.

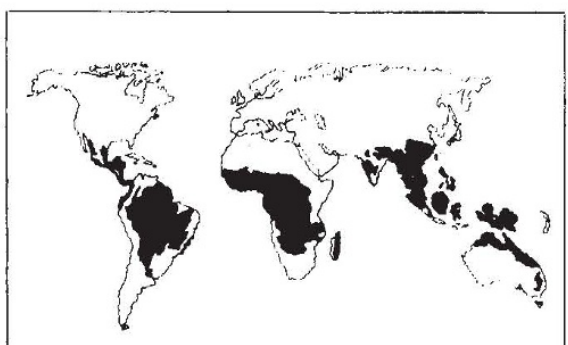

The world's tropical forests (in black)

One reason for the harmonious outcome is the need to persuade hard-nosed politicians, and not just the environmentalists, that the problem is severe enough to demand enormous investment programmes. Gus Speth, president of the World Resources Institute (WDI), likens the global deforestation crisis to the oil crisis faced by industrial countries in the 1970s.

Another reason for the general acceptance is the explicit acknowledgement that the individual countries concerned accept responsibility for helping to solve the problems by encouraging small, rathet than grandiose, projects.

The plan itself, whose main sponsors are WDI, the World Bank and the United Nations Development Programme, calls for a five-year investment of $\$ 8,000$ million to reverse global tropical deforestation and its environmental effects. To prevent the loss of 27 million acres of forest each year from the developing countries, the plan "allocates" $\$ 530$ million to 56 Asian, Latin American and African countries, half of which would be supplied by international lending organizations and half by private investors and the governments of the countries concerned. Large as these figures are, the report stresses that they are small compared with the costs of crisis management. For example, a largely ignored United Nations programme in 1977 recommended that \$50 million a year be spent to avoid desertification in Ethiopia; the report estimates that the Ethiopian famine has since cost $\$ 400$ million in relief programmes, to which at least $\$ 100$ million will be added before the next harvest.

The international task force is confident that it can influence global tropical deforestation, although Speth admits that "we have a distance to go in getting firm pledges of exact dollars" from lending agencies. According to John Spears of the World Bank, the "will exists" to lend but support depends on the participation of individual governments, an opinion echoed by other sponsors of the report.

The report will be presented to the United Nations Commission on Environment and Development in Brazil this week; next month international development assistance agencies meet in the Hague to discuss it. Negotiations are well advanced for a summit meeting "at the highest level" early in 1986.

Maxine Clarke

Tropical Forests: A Call for Action WRI Publications, PO Box 620, Holmes, PA 19(043, \$12.50) (1985).

\section{Big fish love little fish}

\section{Washington}

Two recent acquisitions of start-up biotechnology companies by established pharmaceutical houses may signal the start of a new trend. In September, Eli Lilly and Co. announced its plan to buy Hybritech Inc. of San Diego for over $\mathbf{\$ 3 0 0}$ million, and last week the Bristol-Myers Company announced an agreement in principle to buy Genetic Systems Corporation of Seattle for $\$ 294$ million.

The two deals have a number of similarities. Neither Hybritech nor Genetic Systems was facing a cash crisis, but neither has yet recorded profits. More important, both are hoping to move from reliance on diagnostic products to therapeutics, which are said to cost on average $\$ 100$ million to develop and steer through trials before they receive market approval.

Hybritech already has several diagnostics based on monoclonal antibodies on the market, including pregnancy and cancer tests. It stands to gain much from Lilly's financial and technical resources, as well as marketing knowhow - Lilly is already selling the first human recombinant DNA-derived pharmaceutical, a synthetic insulin.

Much the same can be said for Genetic Systems and Bristol-Myers. Genetic Systems has one diagnostic product on the market, a monoclonal-based test for Legionnaires' disease. Also in the pipeline are HLA cell-typing and tissue-typing reagents, and diagnostics for hepatitis $B$ and acquired immune deficiency syndrome.

It is as yet unclear how the acquisition by Bristol-Myers will affect a previous unconfirmed investment plan by Syntex Corporation, which is a part owner of Genetic Systems. But the deal is not expected to affect Oncogen, an offshoot of Genetic Systems devoted to cancer research and owned jointly by Syntex, Genetic Systems and Bristol-Myers.

Tim Beardsley
Contraceptive pill

\section{Japan heads for legalization}

Tokyo

JAPAN is just coming around to considering the legalization of the contraceptive pill, some twenty years after other major nations. Indeed, with the pill now in use in 150 countries, Japan must be almost the last non-Catholic country and certainly the last industrialized country, in which the pill has been prohibited.

What has brought about this strange state of affairs? Earlier this year Singapore's Prime Minister, Lee Kuan Yew, praised Japan for keeping the ban on the pill as it had helped to retain "Asian values", including "chastity and a high level of fidelity, and the integrity of the family . . .". But officials of the Ministry of Health and Welfare were quick to point out that the pill has been banned only for fear of possible side effects.

That is something of an overstatement. Moral considerations certainly counted when the pill was originally prohibited nearly twenty years ago. But paramount consideration went to the pill's possible side effects, Japan having just experienced thalidomide poisoning and other cases where drug companies found themselves faced with demands for huge compensation payments. Curiously, it now turns out that Japan's attempt to avoid the pill's side effects have rebounded.

Two organizations, the Japan Obstetrics and Gynaecology Society and the Japan Motherhood Protection Medical Association, have now asked the Ministry of Health and Welfare to give permission for clinical tests to be made of the pill. One of the key reasons for their demand is that the pill has actually come into fairly common use. Although doctors are not permitted to prescribe the pill for contraceptive use, they may prescribe it as a medicine, for treatment of irregularities in menstruation, for example.

Using this regulation as a loophole, many doctors now openly provide the pill as a contraceptive. The trouble is that they can prescribe only the high-oestrogen formulations designed for medical rather than contraceptive use. The low-dose pill in use in the United States and Europe is still unknown. The many women who take the pill in Japan thus run a far greater risk of side effects such as thrombosis, than if it had been legalized in the first place.

The Ministry of Health and Welfare has taken the new request positively, but it is not yet clear what action will result. Fresh clinical trials would have to be performed in Japan, even for products in widespread use elsewhere and these are expensive, perhaps costing 3,000 million yen. Any pharmaceutical maker wanting to put a product on the market would thus find itself faced with a very large bill that might 
not be commercially justifiable. A further pressure comes from doctors in the abortion business. who have consistently opposed the pill; for them, abortion services provide a cash income that would be hard to replace. There may well turn out to be a temptation to leave matters as they stand. to the detriment of those taking a high-dose pill.

Alun Anderson

\section{Planetary science}

\section{NASA decision causes dismay}

\section{Washington}

THE decision of the National Aeronautics and Space Administration (NASA) to abandon the Comet Rendezvous and Asteroid Flyby (CRAF) mission as a candidate for a new start in fiscal year 1987 has caused dismay to planetary scientists on both sides of the Atlantic. The mission was to have been the first using the Mariner Mark II Spacecraft, now under development, and there is concern both about the budgetary implications for planetary science and about planning of future missions that may benefit from information provided by CRAF.

NASA's decision resulted from budgetary pressures; the two new starts it has requested for fiscal year 1987 are TOPEX, an oceanographic satellite, and the first part of the US contribution to the International Solar Terrestrial Physics Program. Starting planning for CRAF in 1987 would have meant the agency could look forward to a launch in 1992. The enforced delay makes it likely that a group of engineers working on the Galileo Jupiter spacecraft, now nearing completion, will have to be disbanded rather than moved straight to CRAF, and has shaken the faith of those who expected NASA to continue supporting planetary science to the tune of about $\$ 300$ million a year.

The delay is also likely to impede planning of future missions that might involve collaboration between NASA and the European Space Agency (ESA). ESA is thinking about a sample/return mission to a "primordial body" (asteroid or comet) some time in the next decade that might use CRAF data, and there has been talk about plans for NASA/ESA collaboration on a mission to Saturn, called Cassini, that would, like CRAF, have been based on the Mariner Mark II craft. West Germany is expecting to fly scientific instruments and provide a propulsion module for CRAF, and the decision has caused "great disappointment" there according to one researcher. Dr J. Kissel of the Max Planck institute for nuclear physics said West German scientists would have valued more time to prepare their instrument proposals if the mission is to be delayed on NASA's account; as things stand, NASA is expecting formal proposals before the end of this month.

Tim Beardsley

British astronomy

\section{Lockyer observatory to be sold}

THE future of a trust established by $\mathrm{Sir}$ Norman Lockyer, the editor of Nature from the foundation of the journal in 1869 until his retirement after exactly 50 years, for the benefit of British astronomy is now in doubt. The council of the Norman Lockyer Corporation, the company limited by guarantee which for the time being owns the 44-acre site at Sidmouth, in East Devon, on which Norman Lockyer's observatory is situated, is on the point of selling the largely decrepit collection of telescope domes and buildings to the East Devon District Council for $£ 140,000$.

An attempt by Mr Norman Walker, an astronomer at the Royal Greenwich Observatory (RGO), to rescue the Sidmouth site is meanwhile in limbo. $\mathrm{Mr}$ Walker has been negotiating with the executive council of the Norman Lockyer Corporation, and latterly with the putative owners, the East Devon council, on a plan to refurbish one of the telescopes and to install a 100 -inch reflector in another of the three telescope domes. Mr Walker says that if he could lease the site from one or other of its owners at a reasonable price, he would give up his job, move to Sidmouth and hope to pay for the cost of maintaining the essential buildings on the site by the income from an estimated 50,000 visitors a year to an exhibition he would mount.

Mr Walker's scheme is only the latest in a series of attempts to rescue the Sidmouth scheme in the past two decades, since the Norman Lockyer Corporation formed a loose association with the University of Exeter (then the University College of the South-West) in the heady days of the expansion of the British university system. As things are, there are no funds (and no ambitions) to support a programme of observational astronomy at Exeter, while the cost of keeping the site in some state of order is beyond the resources of the university. A scheme for turning the Sidmouth site into an educational centre for East Devon schools, canvassed a decade ago, similarly came to nothing.

According to $\mathrm{Mr}$ M. J. Hislop, the registrar of the University of Exeter who is secretary of the Norman Lockyer Corporation, negotiations with the East Devon council have been under way for longer than the two years during which $\mathrm{Mr}$ Walker's proposals have been put forward. The proposed selling price for the Sidmouth site is apparently that recommended by the district valuer, a person whose statutory duty is to value property for property taxation purposes. Mr Hislop says that the site is covered by restrictions on development which reduce its value.

Nevertheless, Mr Walker says he is offended that the proposals put to him by the subcommittee appointed by the East
Devon council to look after the proposed purchase are unacceptable. Apparently he has been offered a lease on the part of the site occupied by the three domes and the three other buildings (a workshop, a set of offices and a bungalow) for $£ 47,000$, with a nominal rent for the first few of 90 years, but with the provision that he would not be able to transfer the lease to the handful of colleagues who he hopes will join in the planned flight from RGO to what he hopes will be one of the few remaining sites for observational astronomy in Rritain.

The corporation's view of the future, according to $\mathrm{Mr}$ Hislop, is that the sale to the local council will now almost certainly go ahead, although a decision to dispose of the only substantial asset of the charitable trust would have to be agreed by a meeting of the whole corporation, which appears not yet to have been arranged. Whether Mr Walker can back his plans with firm undertakings of financial support before that meeting is an open question.

One curious feature of these developments is that Lockyer seems to have been over-exact in his design of his charitable trust, whose objects are said to be "to build and maintain observatories for the good of astronomy". The result will be that if the proposed sale goes ahead, the corporation will either have to find some other cognate project on which to spend $£ 140,000$ or arrange that the terms of the trust are changed.

$\mathrm{Mr}$ Hislop says that while the membership of the corporation includes some who were members in Lockyer's time, it now also includes many who have joined to "find out what is going on".

\section{Weizmann Institute \\ Rehovot}

IMMUNOLOGIST Michael Sela, president of the Weizmann Institute for the past ten years, will step down at the end of the month to be replaced by mathematician Aryeh Dvoretzky, now head of the Institute of Advanced Study at the Hebrew University. Sela plans to return to full-time research.

Sela is proudest of his programme of career development chairs, usually endowed by specific donors, by means of which 60 younger scientists have so far benefited. Building work has been given low priority, chiefly because of declining support from the government of Israel.

Best known for his work in synthetic antigens, Sela intends to use a sabbatical year in the United States to develop his interests in synthetic vaccines, multiple sclerosis and the immunological targeting of drugs.
Nechemia Meyers 